ACTA AGROBOTANICA

Vol. 61 (2): 189-194

2008

\title{
DIFFERENTIATION OF MORPHOLOGICAL TRAITS OF COMMON TANSY (TANACETUM VULGARE L.) ORIGINATING FROM DIFFERENT STANDS
}

\author{
Tadeusz Kęsik, Anna Ewa Wojciechowska, Karolina Pitura
}

\author{
Department of Horticultural Plant Cultivation and Fertilization \\ University of Life Sciences in Lublin, Leszczyńskiego 58, 20-068 Lublin, Poland \\ e-mail: tadeusz.kesik@up.lublin.pl
}

Received: 13.02 .2008

S u m m a r y

The aim of the study was to determine the effect of $\mathrm{pH}$ and soil chemical composition on morphological traits of common tansy (Tanacetum vulgare L.). A two-year study was conducted based on observations, measurements and analyses of material collected from 24 stands in the following regions: Równina Włocławska (Włocławek Plain), Wyżyna Lubelska (Lublin Upland), Padół Zamojski (Zamość Depression), Działy Grabowieckie (Grabowiec Divide) Płaskowyż Suchedniowski (Suchedniów Plateau), Wysoczyzna Siedlecka (Siedlce High Plain) and Niecka Połaniecka (Połaniec Basin). Morphological traits of tansy shoots were determined: number of plants per clump, stem length, number of leaves per plant, total leaf length, petiole length, number of branches from the main stem, number of flower heads per corymb and flower head diameter. A soil analysis was performed determining the content of magnesium, potassium and phosphorus available for plants. The soil $\mathrm{pH}$ was also determined. The collected results indicate significant differentiation of the investigated samples, both in terms of morphological traits of the shoots and the chemical composition of the soils. A negative correlation was found between soil $\mathrm{pH}$ and number of leaves per shoot as well as number of branches per corymb. A positive correlation was noted between soil $\mathrm{pH}$ and total leaf length as well as between magnesium content and number of flower heads per corymb. The increased content of available phosphorus in the soil was associated with petiole shortening. A growth trend in the tansy shoot length was observed at larger amounts of available magnesium in the soil. On soils with low nutrient availability and a low $\mathrm{pH}$, a reduced population density of the species in question was observed.

Key words: Tanacetum vulgare L., morphology, soil chemical composition

\section{INTRODUCTION}

Common tansy (Tanacetum vulgare L.) - a perennial plant from the family Asteraceae, is a medicinal plant in which its flower heads (Flos tanaceti) and the tansy herb (Herba tanaceti) are herbal raw material (Kohlm ünzer, 1993 ). It is characterised by a large content of oil whose qualitative composition is unstable and changes, depending on the site of occurrence (M o ckute and Judzentiene, 2004). Because of its anthelmintic and antiparasitic properties, tansy has been commonly used in folk medicine. Research has been recently conducted on the use of Tanacetum vulgare leaf extracts as a medicine with diuretic properties (S a n a et al. 2007 ). Today, due to toxicity of beta-thujone contained in the oil, tansy is mainly used externally in skin diseases. For some time, dried shoots of this plant have been used as ornamental material for dried flower arrangements.

In Poland tansy occurs commonly, forming numerous stands in thicket communities, in forest fringe communities, at ruderal sites ( $\mathrm{S} z \mathrm{z}$ e y k ow s c y, 2003 ). Tanacetum vulgare L. is commonly found across the whole country $(\mathrm{Zaj}$ ą $\mathrm{c}$ and $\mathrm{Zajac}$, 2001). It is due to the availability of this plant that an attempt has been made to determine, based on soil analysis results, the effect of habitat conditions on certain morphological traits of tansy shoots.

\section{MATERIALS AND METHODS}

The study was carried out in the years 2005 and 2007. 24 natural common tansy stands were selected from different Poland's regions: Równina Włocławska (Włocław Plain), Wyżyna Lubelska (Lublin Upland), Padół Zamojski (Zamość Depression), Działy Grabowieckie (Grabowiec Divide) Płaskowyż Suchedniowski (Suchedniów Plateau), Wysoczyzna Siedlecka (Siedlce High Plain) and Niecka Połaniecka (Połaniec Basin). From each site, a soil sample was collected from the soil layer of 0-20 cm and biometric measurements of plants were made. In the soil, the content of macroelements: potassium and phosphorus, was determined 
using Egner-Riehm's method, magnesium using the colorimetric method and the $\mathrm{pH}$ by means of the potentiometric method in $1 \mathrm{n} \mathrm{KCl}$.

At the turn of July and August each year, during the full flowering period, biometric analyses were performed in three replications. The characteristics of shoot morphological traits included the following: number of plants per clump, stem length, number of leaves per plant, total leaf length, petiole length, number of branches from the main stem, number of flower heads per corymb and their diameter.

\section{RESULTS AND DISCUSSION}

The soil reaction in the natural tansy stands was quite varied; the $\mathrm{pH}$ in $\mathrm{KCl}$ was from acid - 4.0 ( stand no. 3), to alkaline -7.4 (stands no. 6., no. 15 ., no. 22.). The obtained results show high tolerance of this plant to the hydrogen ion concentration in the soil. However, only in $8.4 \%$ of the stands concerned, a pH below 5.0 was found. This result may prove that common tansy prefers slightly acid and neutral soils. This finding finds confirmation in a paper characterising some morphological features of vascular plants of the Lublin region (F i j a łk ow ski, 1994). The author gives a soil pH from 5.5 to 6.5 as the optimal soil reaction.

Soils of mainly loess origin, with high nutrient availability, were characterised by a higher soil $\mathrm{pH}$ (stand no. 6, 8, 15).

The mineral content varied strongly. The plants grew equally well on soils with a very high content of phosphorus (50 mg $\times 100 \mathrm{~g}^{-1}$ soil) and potassium (30 mg $\times 100 \mathrm{~g}^{-1}$ soil), where the tansy shoot length reached $141.3 \mathrm{~cm}$, and in stands deficient in these nutrients $\left(1.7 \mathrm{mg} \mathrm{P} \times 100 \mathrm{~g}^{-1}\right.$ soil and $1.6 \mathrm{mg} \mathrm{K} \times 100 \mathrm{~g}^{-1}$ soil) (Tab. 1.) in which the length of the plant shoot was 104.6 and $163.3 \mathrm{~cm}$, respectively (Tab. 2). Soil conditions characterising nutrient requirements of the plant in question were marked by high diversity, also in terms of magnesium availability. Tansy occurred in stands with a large (15.7 mg Mg $\times 100 \mathrm{~g} \mathrm{~g}^{-1}$ soil) and even trace amount of this element in the soil $(1.0 \mathrm{mg}$ $\mathrm{Mg} \times 100 \mathrm{~g}^{-1}$ soil (Tab. 1).

In available literature, no reference has been found relating to nutrient requirements of Tanacetum vulgare L., however, a paper on the distribution of this species in Poland indicates the common occurrence of tansy throughout the whole country ( $\mathrm{Z} \mathrm{aj}$ a c and $\mathrm{Zajac}$, 2001). Such common availability of this plant undoubtedly proves the high tolerance of the species in question to the content of bioelements in soil.

Measurements related to the growth and flowering of the herb prove large differentiation in terms of morphology of this plant.
Tansy grew most frequently in clusters forming clumps with a different number of shoots, from 8.0 - stand no. 21 - up to 39.3 in stand no. 4 . The shoot length was also quite varied; the plant developed shoots with a height from $66 \mathrm{~cm}$ to $163 \mathrm{~cm}$. These values are higher by, respectively, 5.5 and $47.9 \mathrm{~cm}$ than the results given in a paper relating to genetic and morphological diversity of tansy (Keskitalo et al. 1998). The authors of this article also estimated the number of flower heads per corymb, which was from 17.6 to 79.8 . The range of results in our study was much wider. Differences in the shoot length given by $\mathrm{S} z$ a fe $\mathrm{r}$ et al. (1969) - from 50 to $150 \mathrm{~cm}$, are similar to the results obtained in our study.

The plants were characterised by large variability in leaf morphological traits, notably, the number of leaves per shoot ranged between 7.3 (stand no. 4) and 37 (stand no. 3.) and it was in no way dependent on the number of shoots per clump or their length.

Total leaf length and petiole length also had different values not related to other morphological traits of the herb. The longest leaves were observed on the plants from stand no. $13 .(25.5 \mathrm{~cm})$ and the same plants were characterised by the longest petioles. The smallest total leaf length related to the plants from stand no. 22. and it was $12.5 \mathrm{~cm}$.

The shortest petioles $(1.5 \mathrm{~cm})$ were found in Czesławice in stand no. 8 .

Large differences in the number of branches in corymbs from 7 (stand no. 1) to 20 (stand no. 17.) did not determine the correlation between the equally varied number of flower heads per corymb (26.8 at stand no. 14. and 310.6 at stand no. 23.).

The flower head diameter ranged from $0.55 \mathrm{~cm}$ in stand no. 8. to $1.07 \mathrm{~cm}$ in Lublin - stand no. 4 . The abovementioned data evidence large variability of this trait. These results are consistent with the range of flower head diameters given by B rod a and Mow szowicz (2000), which is from 0.8 to $1.1 \mathrm{~cm}$ in their paper. Taking into account the fact that inflorescences are herbal raw material and they contain more oils than leaves by $36.7 \%$ and by as much as $69.4 \%$ than the herb, the flower head diameter will affect an increase in yield (Wierzchowska-Renke et a1. 1997).

All the abovementioned traits, both of substrate and plant morphology, indicate the high tolerance of tansy in relation to the soil reaction as well as phosphorus, potassium and magnesium content in soil.

A factor modifying the plant growth, expressed by the shoot length, was the availability of assimilable magnesium in the soil. At the majority of the sites, a high content of this element in the soil solution promoted the growth of the developed shoots (Tab. 3). This correlation was not observed in all the stands 
Table 1

Nutrient content $\left(\mathrm{mg} \times 100 \mathrm{~g}^{-1}\right.$ soil) and soil $\mathrm{pH}$.

\begin{tabular}{|c|c|c|c|c|c|}
\hline No. & Stand & $\mathrm{pH}$ & $\mathrm{Mg}$ & K & $\mathrm{P}$ \\
\hline & Równina Włocławska & & & & \\
\hline 1. & Włocławek - Zgłowiączka River & 6.5 & 8.5 & 12.5 & 21.8 \\
\hline \multirow[t]{2}{*}{2.} & Włocławek - forest & 7.3 & 4.3 & 5.4 & 17.0 \\
\hline & Wyżyna Lubelska & & & & \\
\hline 3. & Niemce - cemetery & 4.0 & 1.0 & 4.3 & 4.0 \\
\hline 4. & Lublin - Felin boundary strip & 7.2 & 3.1 & 19.2 & 25.2 \\
\hline 5. & Lublin - Choiny lawn & 7.3 & 11.1 & 35.7 & 23.6 \\
\hline 6. & Lublin - Chodźki waste land & 7.4 & 12.5 & 35.2 & 25.8 \\
\hline 7. & Drzewce - boundary strip & 6.9 & 14.3 & 17.6 & 13.2 \\
\hline 8. & Czesławice - railway embankment & 7.2 & 15.7 & 30.0 & 50.0 \\
\hline 9. & Łopatki - roadside & 7.2 & 13.9 & 19.6 & 25.4 \\
\hline 10. & Olempin - spruce thicket & 7.1 & 1.3 & 3.7 & 13.0 \\
\hline 11. & Olempin - roadside & 6.2 & 6.9 & 21.8 & 19.0 \\
\hline 12. & Olempin - landfill & 6.2 & 4.3 & 18.7 & 25.0 \\
\hline 13. & Lublin - ravine & 7.3 & 8.0 & 5.8 & 3.0 \\
\hline 14. & Lublin - waste land & 7.3 & 7.3 & 19.9 & 9.9 \\
\hline \multirow[t]{2}{*}{15.} & Michałów - fallow field & 6.9 & 4.7 & 1.7 & 14.3 \\
\hline & Padół Zamojski & & & & \\
\hline \multirow[t]{2}{*}{16.} & Zamość - lawn & 7.4 & 7.4 & 20.7 & 11.9 \\
\hline & Działy Grabowieckie & & & & \\
\hline \multirow[t]{2}{*}{17.} & Tarzymiechy - boundary strip & 7.3 & 7.3 & 20.7 & 9.8 \\
\hline & Płaskowyż Suchedniowski & & & & \\
\hline 18. & Suchedniów - railway embankment & 6.7 & 5.9 & 14.0 & 4.0 \\
\hline 19. & Suchedniów - homestead garden & 5.3 & 5.6 & 11.0 & 18.5 \\
\hline & Wysoczyzna Siedlecka & & & & \\
\hline 20. & Siedlce - beach on a man-made lake & 6.6 & 9.1 & 23.3 & 21.8 \\
\hline \multirow[t]{2}{*}{21.} & Golice - fallow field & 6.5 & 8.7 & 22.8 & 24.0 \\
\hline & Niecka Połaniecka & & & & \\
\hline 22. & Połaniec - on the Vistula River & 7.4 & 13.2 & 14.1 & 6.9 \\
\hline 23. & Połaniec - cemetery & 4.5 & 11.3 & 3.9 & 1.7 \\
\hline 24. & Połaniec - fallow field & 5.0 & 2.8 & 1.6 & 4.5 \\
\hline
\end{tabular}




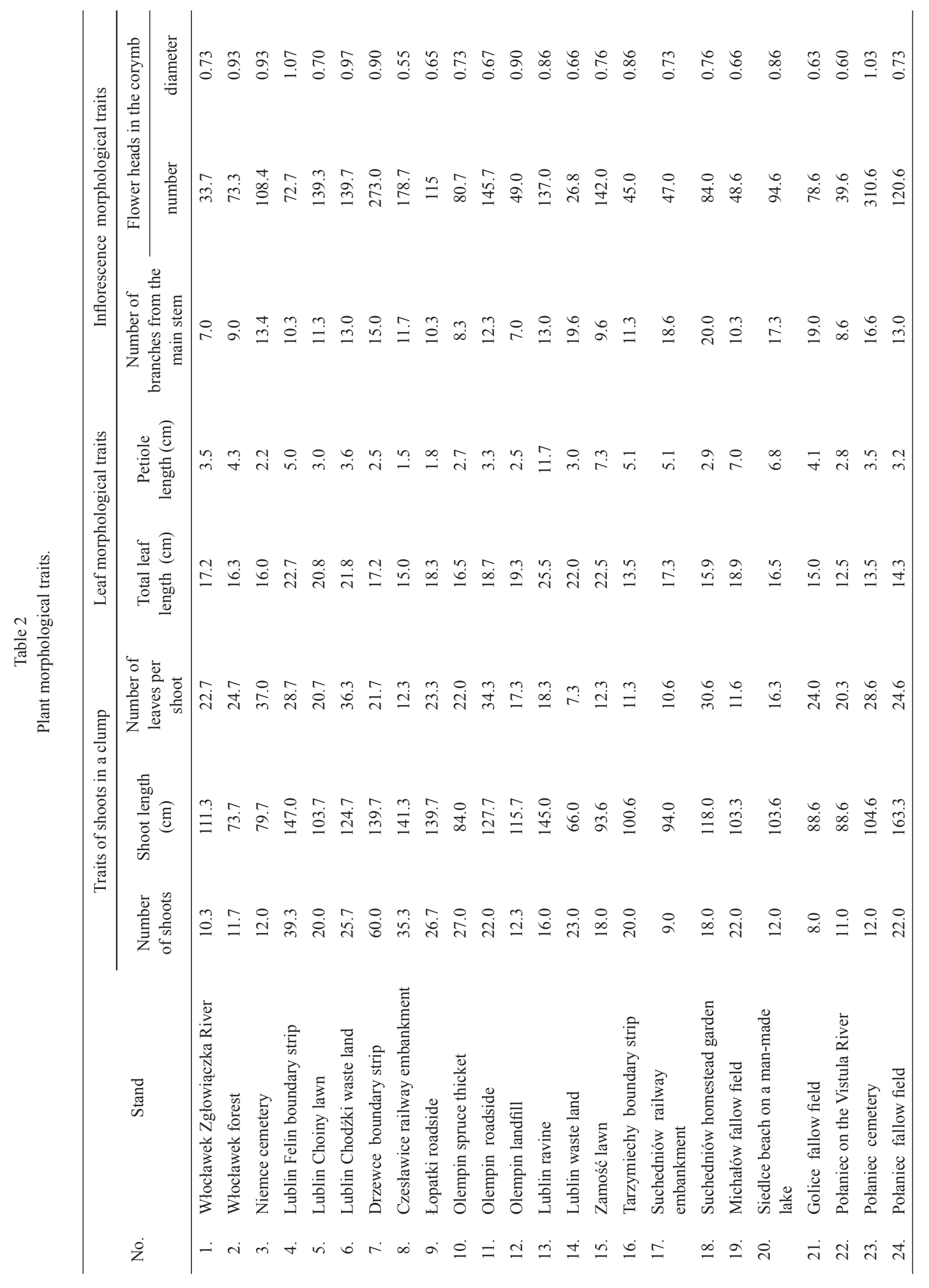


Table 3

The correlation coefficient for nutrient content and soil $\mathrm{pH}$ and plant morphological trait.

\begin{tabular}{|c|c|c|c|c|c|c|c|c|}
\hline & \multicolumn{2}{|c|}{$\begin{array}{l}\text { Number and length } \\
\text { of shoots in a clump }\end{array}$} & \multicolumn{3}{|c|}{ Leaf morphological traits } & \multicolumn{3}{|c|}{ Inflorescence morphological traits } \\
\hline & $\begin{array}{l}\text { Number } \\
\text { of shoots }\end{array}$ & $\begin{array}{l}\text { Shoot } \\
\text { length } \\
(\mathrm{cm})\end{array}$ & $\begin{array}{l}\text { Number } \\
\text { of leaves } \\
\text { per shoot }\end{array}$ & $\begin{array}{l}\text { Total leaf } \\
\text { length } \\
(\mathrm{cm})\end{array}$ & $\begin{array}{l}\text { Petiole } \\
\text { length } \\
(\mathrm{cm})\end{array}$ & $\begin{array}{l}\text { Number of } \\
\text { branches from } \\
\text { the main stem }\end{array}$ & $\begin{array}{l}\text { Number of } \\
\text { flower heads } \\
\text { per corymb }\end{array}$ & $\begin{array}{l}\text { Flower head } \\
\text { diameter } \\
(\mathrm{cm})\end{array}$ \\
\hline $\mathrm{pH}$ & +0.27 & -0.04 & -0.50 & 0.42 & +0.26 & -0.31 & -0.28 & -0.25 \\
\hline $\begin{array}{c}\mathrm{Mg} \\
\left(\mathrm{mg} \times 100 \mathrm{~g}^{-1} \text { soil }\right)\end{array}$ & +0.29 & +0.24 & -0.12 & -0.08 & -0.17 & +0.09 & +0.47 & -0.26 \\
\hline $\begin{array}{c}\mathrm{K} \\
\left(\mathrm{mg} \times 100 \mathrm{~g}^{-1} \text { soil }\right)\end{array}$ & +0.22 & +0.10 & -0.07 & +0.25 & -0.20 & +0.07 & +0.06 & -0.15 \\
\hline $\begin{array}{c}\mathrm{P} \\
\left(\mathrm{mg} \times 100 \mathrm{~g}^{-1} \text { soil }\right)\end{array}$ & +0.29 & +0.28 & -0.002 & +0.07 & -0.33 & -0.20 & -0.01 & -0.24 \\
\hline
\end{tabular}

(stands no.: 1, 2, 14, 19, 22, and 24.). Most probably, other habitat factors were active at these sites, limiting the uptake of the bioelement or making the plant height independent of the amount of the respective nutrient in the soil (Tab. 2., stands no. 19. and 24.). An example may be a forest stand (Włocławek no. 2.) where the extensive shading of this area was probably the cause of the plant's limited growth $(73.3 \mathrm{~cm}$. But, in the same city in a stand near the Zgłowiączka River $(113.3 \mathrm{~cm})$ and in Połaniec on the Vistula river $(88.6$ $\mathrm{cm})$, the small shoot length, compared to the magnesium content in the soil, was most probably attributable to disturbances in the uptake of this element. These sites were periodically inundated.

The longest tansy shoots measured in the following stands: no. 4. Lublin Felin boundary strip (147 $\mathrm{cm})$ and no. 24. Połaniec fallow field $(163.3 \mathrm{~cm})$, prove that a low magnesium and potassium content in the soil (Tab. 1.) is not a factor limiting the growth of Tanacetum vulgare.

The correlation between shoot length and magnesium content in the soil does not find any confirmation in scientific literature.

The analysis of the correlation showed a negative correlation between soil reaction and number of leaves per shoot $(-0.50)$ and number of branches per corymb (-0.31). A positive correlation was noted between soil $\mathrm{pH}$ and total leaf length $(+0.42)$ as well as between magnesium content and number of flower heads per corymb $(+0.37)$.

The level of available phosphorus in soil was found to be negatively correlated to petiole length $(-0.33)$.
No other correlations were found between the content of macroelements in the soil and morphological traits of the plants. A beneficial effect of potassium on plant conformation and a negative effect of phosphorus on number of shoots and branches of St. John's wort were found in a paper by B ła ż e w i c zWoźniak and Kęsik (2001). A negative correlation was also shown between the magnesium level in the soil and the height of the investigated plants.

Large differentiation in morphological traits of tansy is most probably associated not only with soil chemical conditions, but also with other habitat factors such as: light, interspecific competition and the anthropogenic factor.

\section{CONCLUSIONS}

1. Common tansy plants were characterised by large differentiation in the morphological structure of their shoots.

2. Tansy grew well both on soils with an acid and neutral reaction. In natural stands, however, it prefers soils with a higher $\mathrm{pH}$.

3. The species Tanacetum vulgare L. occured in stands with a very varied content of the following nutrients: potassium, phosphorus and magnesium.

4. A positive correlation was demonstrated between soil reaction and total leaf length, as well as a negative effect of soil $\mathrm{pH}$ on number of leaves per shoot and number of branches per corymb.

5. The magnesium level in the soil had a beneficial effect on number of flower heads per corymb.

6. A negative correlation was noted between phosphorus content in soil and petiole length. 


\section{REFERENCES}

Broda B., Mowszowicz J., 2000. Przewodnik do oznaczania roślin leczniczych trujących i użytkowych, / Guide for identification of medicinal, poisonous and commercial plants. Wydawnictwo Lekarskie PZWL: 718.

Błażewicz-Woźniak M., Kęsik T., 2001. Niektóre cechy wzrostu dziurawca zwyczajnego ( Hypericum perforatum L. ) zbieranego ze stanowisk naturalnych regionu środkowowschodniego. / Some growth traits of St. John's wort ( Hypericum perforatum L. ) collected from natural stands of the central-eastern region. Ann. UMCS sect. EEE Suppl. 9: 279-286.

Fijałkowski D., 1994. Flora roślin naczyniowych Lubelszczyzny. / Flora of vascular plants of the Lublin region. Lubelskie Towarzystwo Naukowe, Lublin: 312, 343.

Keskitalo M. et al., 1998. Genetic and morphological diversity of Finnish tansy (Tanacetum vulgare L., Asteraceae), Theor Apel Genet. 96: 1141-1150.

Kohlmünzer S., 1993. Farmakognozja Podręcznik dla studentów farmacji. Wydawnictwo Lekarskie PZWL: 585.

Mockute D., Judzentiene A., 2004. Composition of Essential Oils of Tanacetum vulgare L. Growing Wild in Vilnius District (Lithuania), J. Essent. Oil Res. 16: 550553.

Sanaa L. i in. 2007. Diuretic activity of the aqueous extracts of Carum carvi and Tanacetum vulgare in normal rats, Ethnopharmacology, 110 issue 3: 458-463.

Szafer W., Kulczyński S., Pawłowski B., 1969. Rośliny Polskie, / Polish plants. PWN Warszawa: 68.

Szweykowscy A. and J., 2003. Słownik botaniczny / Botanical dictionary, PW Warszawa: 1004-1005.

Wierzchowska-Renke K. i in., 1998. Wpływ bliskości ciagów komunikacyjnych na skład chemiczny Achillea millefolium L. i Tanacetum vulgare L. / The effect of proximity of transport routes on the chemical composition of Achillea millefolium L. and Tanacetum vulgare L. Herba Polonica, 44: 353-360.

Zając A., Zając M. (red.), 2001. Atlas rozmieszczenia roślin naczyniowych w Polsce / Distribution atlas of vascular plants in Poland, Nakładem Pracowni Chorologii Komputerowej Instytutu Botaniki Uniwersytetu Jagiellońskiego, Kraków.

\section{Zróżnicowanie cech morfologicznych wrotycza pospolitego (Tanacetum vulgare L.) pochodzącego $\mathrm{z}$ różnych stanowisk}

\author{
Streszczenie
}

Celem pracy było określenie wpływu odczynu i składu chemicznego gleby, na cechy morfologiczne wrotyczu pospolitego (Tanacetum vulgare L.). Dwuletnie badanie zostały przeprowadzone na podstawie obserwacji, pomiarów i analiz materiału pobranego z 24 stanowisk rejonów: Równiny Włocławskiej, Wyżyny Lubelskiej, Padołu Zamojskiego, Działów Grabowieckich, Płaskowyżu Suchedniowskiego, Wysoczyzny Siedleckiej oraz Niecki Połanieckiej. Oznaczono cechy morfologiczne pędów wrotyczu: liczbę roślin w kępie, długość łodygi, liczbę liści na roślinie, długość całkowitą liści, długość ogonka liściowego; liczbę rozgałęzień od głównego pędu, liczbę koszyczków w podbaldachu oraz średnicę koszyczków. Wykonano analizę gleby określając zawartość dostępnego dla roślin magnezu, potasu i fosforu. Oznaczono również pH gleby. Zebrane wyniki wskazują na znaczne zróżnicowanie badanych prób zarówno pod względem cech morfologicznych pędów jak i składu chemicznego gleb. Stwierdzono ujemny związek pomiędzy odczynem gleby a liczbą liści na pędzie oraz liczbą rozgałęzień w podbaldachu. Dodatnią korelację odnotowano pomiędzy $\mathrm{pH}$ gleby a długością całkowita liści, a także między zawartością magnezu, a liczbą koszyczków w podbaldachu. Zwiększona zawartość dostępnego fosforu w glebie wiązała się ze skróceniem ogonka liściowego. Zaobserwowano tendencję wzrostową dla długości pędów wrotyczu przy większej ilości przyswajalnego magnezu w glebie. Na glebach mało zasobnych i o niskim $\mathrm{pH}$ zauważono ograniczoną liczebność występowania populacji omawianego gatunku. 